\title{
Active and Passive Students' Listening Strategies
}

\author{
Ramin Taherkhani \\ Faculty of Humanities, Islamic Azad University, Takestan Branch, Iran \\ Email: ramin_taherkhani2010@yahoo.com
}

\begin{abstract}
To determine the relationship between active and passive student's listening strategies, 70 students (all beginners) were selected. All subjects who were the researcher's students participated in four data gathering sections. They took Raven IQ test, attention test, Irenck Lie test, and strategy questionnaire. The results of the IQ and attention tests divided the subjects in to active and passive groups. 20 subjects were eliminated from the study due to their responses to the Irenck Lie test. 50 subjects remained for the rest of the study. Student's responses to the strategy questionnaire revealed a strong relationship between both group s in this order of importance: (a) person knowledge. (b) strategy knowledge, (c) task knowledge (d) strategy knowledge, (e) task knowledge. The strategies that were not selected by both groups were metacognitve and strategy knowledge. In this study active group outperformed passive ones both in the range and type of listening strategies.
\end{abstract}

Index Terms - active student, passive student, listening, strategies

\section{INTRODUCTION}

Listening is an active information process ability. In this active process students receive and construct information. As a result, listening is actually more than hearing (Rost, 1990). In this particular ability, students use different strategies during listening. Active students use their own strategies and passive ones apply their own strategies during listening process (Rost, 1991).

In recent years the main focus of teachers and researchers is on knowing these strategies (O’Malley \& Chamot, 1989). By using different techniques they elicit these strategies from students. In fact these strategies should be found in student's minds. Here, teachers try to find the active student's strategies during listening and teach them to passive students. Teaching these strategies (i.e., active students strategies to passive students), teachers hope to help passive students and enable them to over come their difficulties in listening comprehension.

Strategies are the specific methods and techniques employed by the students for processing the input language information (Willing, 1985, pp. 278-9). Strategies are hence viewed as a way of managing the complex information that the learner is receiving about the target language.

These techniques and strategies help the students to facilitate their own learning. In order to collect data about listening strategies, researchers can use "think - aloud" procedures in which students are interrupted during a listening comprehension activity and asked to indicate what they were thinking. Teachers can tape- record the voice of a student during the time he explains what he was thinking. After interviewing both passive and active students, researchers can obtain the data. These findings will show the different strategies used by both groups. Teachers can also provide their students with listening material sand ask them to listen to these materials at home (Goh, 1997). Here. The students are required to write diaries at home during the listening process and indicate the strategies they used during this process.

Another technique for collecting data about learning strategies is the use of questionnaire. In this method students are allowed to select the strategies that are mentioned in the questionnaire. By comparing the active and passive student's strategies, the researcher can differentiate among them. According to O' Malley and Chamot (1989) the advantage of questionnaire in collecting data is in delimiting the responses to information that is relevant and in simplifying data manipulation since you can code and analyze the data.

\section{THE CURRENT STUDY}

\section{A. Participants}

The participants for this research consisted of 70 students at both guidance and high school levels. 30 students enrolled in second grade at guidance school, 15 in third grade at guidance school, and 25 in first grade at high school levels. At this center, the students are required to study English in the 2nd grade at guidance school. Because the number of students were small, this school followed the coeducational system at guidance school level. All the subjects were the researcher's students and they participated their English classes 4 hours a week. They were engaged in listening to English tapes, prepared by Ministry of Education, 2 hours a week.

\section{B. Instruments}


The data were collected using four separate instruments: (a) the IQ test of Raven, (b) an article of a Persian news paper which asked the students to underline the /I:/ sound(attention test), (c) the Lie test of Eyrenck, and (d), the listening strategy questionnaire to assess student's reported self-perception of their listening comprehension strategies.

\section{Procedure}

The research was conducted at a small school with the students studying English as a foreign language. Eleven wellrecognized listening strategies were introduced to the students during their listening course. The date gathering sessions were conducted in the student's own classrooms during regular class time to minimize the impact of the environment. More over, in order to reduce the student's stress, one of the researcher's colleagues administered the tests. To perform their tasks eagerly, the students were paid money after completing each test. All the tests were written in Persian language since the students were beginners. After completing the first task, the listening strategy, which took 15 minutes all the answer sheets were gathered.

In the second task, the IQ hand books and answer sheets were distributed among the students. The subjects were instructed how to perform the task. This session took the longest time of the administration. After 45 minutes all answer sheets and hand books were gathered. During the third task, the subjects were asked to under line the /I:/ sounds of a Persian article. This article contained 100 /I:/ sounds and was selected from a Persian newspaper.After 10 minutes all the answer sheets were gathered. For the fourth task, the students were instructed to give Yes/No responses to the Lie test of Eyrenck during 10 minutes.

\section{Data Analysis}

In order to calculate the student's IQ, their responses to the IQ test were checked. Then by subtracting their date of birth from the date of the administration of the IQ test, the students ages were accounted. In order to change the raw scores of IQ in to their equal IQ, the Table of Raven test for the students in province Qazvin was used.

The attention tests were checked by accounting the number of the underlined /I:/ sounds. This test contained 100 /I:/ sounds and each sound received one score. After checking the student's answers to the lie test, the students whose scores exceeded 14 were eliminated from the study. This test had 20 items and each Item received one score.

The listening strategy Questionnaires were checked for the strategy comparison. This questionnaire included eleven well- recognized active listening strategies. The students were to select the strategies they used when listening to English language.

\section{RESULTS}

The results of the Lie tests were examined through the students answers to the Lie test. After checking the student's responses to the Lie test, 20 subjects were eliminated from the study and 50 subjects remained for the rest of the study. According to the personality test of Eyrenck for IRANIAN teenagers, prepared by the Ministry of Education, the scores above 14 are not reliable. In other words, the student who scored more than 14 in the Lie test of Eyrenck, he is in the critical status. Therefore, his responses are not reliable in selecting listening strategies.

The responses to IQ test and attention test were used to separate the students in to active and passive groups. In fact, the student whose IQ exceeded 100 fell in to active group; on the other hand the student with the IQ of lower than 90 fell in to passive group. Using Table of Raven for the students in Province Qazvin, the raw scores of IQ were changed in to their equal IQ. As a result of the student's responses to the IQ tests 25 students fell in to active group and 25 students were placed in to passive group. The range of IQ in the active group was from 100 to 120 and the IQ of passive group ranged from 75 to 90 .

As a results of the student's scores on the attention testes 25 fell in to active group and 25 were placed into passive one .By accounting the number of underlined /I:/ sounds, the student's attention were calculated. Here, the subjects whose score exceeded 90 from 100 were placed in to active group and the subjects with the attention of lower than 90 fell in to passive group. The range of attention scores in the active group was from 90 to 100 and in the passive group the attention scores ranged from 60 to 85 .

In this study the student's active participation in English class were also taken in to consider. The results of the subject's scores on IQ and attention tests supported their active class participation.

The relationship between active and passive student's listening strategies was examined through the students' responses to the strategy questionnaire. Relationships between active and passive student's listening strategies were found by using Pearson's correlation coefficient to compare the result of strategy questionnaire. The relationship between active and passive group's listening strategies were noticeably strong $(\mathrm{r}=0 / 81, \mathrm{p}<01)$. The correlation coefficient of strategy use between both groups were calculated $(r=0 / 81)$. Upon closer observation of the student's strategy selection, the researcher saw strong relationships at some strategies. The strategies they selected the most in common are as follows: (a) searching for meaning, (b) considering the context and color of word, (c) knowing whether close or cursory listening is required, (d) checking their understanding, (e) taking few notes, (f) giving complete attention to the task. Subjects selected these strategies in the above order of importance. 
TABLE 1

SELECTED USE OF DURING LISTENING STRATEGIES

\begin{tabular}{|c|c|c|c|}
\hline Listening strategies & & Active group & Passive group \\
\hline 1. I give complete attention to the task and demonstrate interest. & $\begin{array}{r}\text { Agree } \\
\text { Undecided }\end{array}$ & $\begin{array}{l}56 \% \\
44 \%\end{array}$ & $\begin{array}{l}12 \% \\
88 \%\end{array}$ \\
\hline 2. I search for the meaning of the words. & $\begin{array}{c}\text { Agree } \\
\text { Undecided }\end{array}$ & $\begin{array}{l}96 \\
4\end{array}$ & $\begin{array}{l}84 \\
16\end{array}$ \\
\hline 3 ....I constantly check my understanding of the message. & $\begin{array}{c}\text { Agree } \\
\text { Undecided }\end{array}$ & $\begin{array}{l}76 \\
20\end{array}$ & $\begin{array}{l}24 \\
80\end{array}$ \\
\hline $\begin{array}{l}4 \ldots . \text { I check my understanding by making connections with people, } \\
\text { places, situations and ideas I know. }\end{array}$ & $\begin{array}{c}\text { Agree } \\
\text { Undecided }\end{array}$ & $\begin{array}{l}00 \\
100\end{array}$ & $\begin{array}{l}00 \\
100\end{array}$ \\
\hline $\begin{array}{l}5 \ldots . . \mathrm{I} \text { check my understanding by determining what will be said } \\
\text { next. }\end{array}$ & $\begin{array}{c}\text { Agree } \\
\text { Undecided }\end{array}$ & $\begin{array}{l}8 \\
92\end{array}$ & $\begin{array}{l}00 \\
100\end{array}$ \\
\hline $\begin{array}{l}6 \text {...I check my understanding by determining speaker's intent } \\
\text { infer what the speaker doesn't say, responding to what has been } \\
\text { said and passing judgment }\end{array}$ & $\begin{array}{c}\text { Agree } \\
\text { Undecided }\end{array}$ & $\begin{array}{l}24 \\
76\end{array}$ & $\begin{array}{l}00 \\
00\end{array}$ \\
\hline $\begin{array}{l}7 \ldots . \text { I know whether close or cursory listening is required and adjust } \\
\text { my behavior accordingly . }\end{array}$ & $\begin{array}{c}\text { Agree } \\
\text { Undecided }\end{array}$ & $\begin{array}{l}72 \\
28\end{array}$ & $\begin{array}{l}60 \\
40\end{array}$ \\
\hline $\begin{array}{l}8 \ldots . . \mathrm{I} \text { am ready to take notes, outline, map, categorize, I sift and } \\
\text { sort and add my own information. }\end{array}$ & $\begin{array}{c}\text { Agree } \\
\text { Undecided }\end{array}$ & $\begin{array}{l}00 \\
100\end{array}$ & $\begin{array}{l}00 \\
100\end{array}$ \\
\hline 9 ....I take fewer and meaningful notes. & $\begin{array}{c}\text { Agree } \\
\text { Undecided }\end{array}$ & $\begin{array}{l}76 \\
24\end{array}$ & $\begin{array}{l}20 \\
80\end{array}$ \\
\hline 10....I distinguish message from the speaker. & $\begin{array}{c}\text { Agree } \\
\text { Undecided }\end{array}$ & $\begin{array}{l}8 \\
92\end{array}$ & $\begin{array}{l}00 \\
100\end{array}$ \\
\hline $11 \ldots . . \mathrm{I}$ consider the content and color of words. & $\begin{array}{c}\text { Agree } \\
\text { Undecided }\end{array}$ & $\begin{array}{l}76 \\
24\end{array}$ & $\begin{array}{l}72 \\
28\end{array}$ \\
\hline
\end{tabular}

The researcher has also found the existence of another relationship between the groups. In fact, all the subjects did not select some strategies. The strategies they did not select were making connections, categorizing, mapping and outlining. Some strategies were selected only by active group. They were (a) determining what will be said next, (b) distinguishing the message from the speaker.

\section{DISCUSSION}

Throughout the report of the results of this study, the researcher offered some speculative thought on why certain data displayed the way they did. In this section in order to understand further the implications of this study, observations of the results will first be presented in terms of cognitive strategies and metacognitive strategies. According to Rubin Joan (1994) cognitive strategies involve how to store and retrieve information. Metacognitive strategies involve planning monitoring, and evaluating comprehension. In addition to metacognitive strategies, listeners use metacognitive knowledge about themselves and how they listen best (person knowledge), about how much text to listen to, how difficult a text is etc, (i.e., task knowledge), and about strategies and their relation to text and tasks (i.e., strategy knowledge).

In general terms, the results showed that although all the learners were aware of all the strategies mentioned in the questionnaire, they did not select connection with people, places, and ideas (i.e., metacognitive strategy), and outlining, stiffing and sorting, and adding one's information (i.e., strategy knowledge).

On the other hand the strategies only selected by active group were determining the speaker's intent and infer what has not been said, determining what will be said next (i.e., both metacognitive strategies). The same relationship surfaced with person knowledge in that nobody in the passive group reported distinguishing message from the speaker (i.e., person knowledge).

According to their responses, the subjects selected using the following strategies in common and in this order of importance: (a) searching for meaning, (b) considering the context and color of words, (c) knowing close or cursory listening is required, (d) checking their understanding, (e) taking fewer notes, and (f) giving complete attention to the task. Here, we see person knowledge (a) and strategy knowledge (b) occupied the strong relationship between both groups. The same relationship surfaced with (c) which is a task knowledge. The strategies that were selected the least in common by both groups were metacognitive strategy (d) strategy knowledge (e) and task knowledge (f).

Form a global perspective, the results of this study indicated that person knowledge, strategy knowledge, and task knowledge revealed the strongest relationships. In the case of searching for meaning of words (person knowledge). The reason could be lied in the fact that the subjects in this study were beginners. They found themselves less capable of performing the integrative skills for listening comprehension and had to rely on the more discrete skills, like searching for meaning. On the other hand the strategy knowledge and task knowledge are less integrative in comparison to metacognitive strategies. 
The strategies that were selected the least in common by both groups were checking one's understanding (i.e., metacognitive strategy), note taking (strategy knowledge) and attention to listening (task knowledge). These strategies particularly metacognitive one were among the integrative strategies and as the results revealed active students outperformed the passive ones in these strategies.

Some strategies were not selected by all participants in this study. They were connection (i.e., metaconitive strategy) and outlining, sifting and sorting (i.e., strategy knowledge). These strategies might be among the most integrative strategies; however, all participants were a were of them. What does all of this suggest?

First, this study suggests that active students outperformed the passive ones both in range and type of listening strategies.

Second, although the students had the required knowledge, skills and strategies to listen and learn, they did not seem to use them as effectively as they should. Being strategic is not simply a matter of knowing what strategy to use but also how to use it successfully.

This is what Baker and Brown (1984) called the separation between "knowing what" and "knowing how" These results in fact paralleled Baker and Brown's findings (1984). This subject might be discussed from another perspective in linguistics in that one's performance is lower than his competence.

Third, the fact that active students outperformed the passive ones do not reject the existence of relationship between them. There was a strong correlation between their strategy use $(r=0.81, p<01)$. Therefore, the null hypothesis was rejected. In other words, all of the participants have selected some strategies, but the range and type of strategies appeared to differ between them. The active group perceived themselves to be the most strategic listeners and outperformed the passive group.

\section{CONCLUSION}

Students do not have an innate understanding of what effective listeners do; therefore, it is the responsibility of teachers to share that knowledge with them. Perhaps the most valuable way to teach listening skills for teachers is to model them themselves, creating an environment which encourages listening. Teachers can create such an environment by positive interaction, actively listening to all students and responding in an open and appropriate manner. Teachers should avoid responding either condescendingly or sarcastically. As much as possible, they should minimize distractions and interruptions. It is important for teachers to avoid numerous opportunities for students to practice listening skills and to become actively engaged in the listening process. The results of the study have shown that both active and passive students made use of listening strategies. However, active group outperformed passive ones both in type and range of strategy use.

\section{REFERENCES}

[1] Goh, C. (1997). Metacognitive awareness and SL listeners in ELT Journal volume 57/4 October 1997; Oxford university press 1997.

[2] O'Malley, J M and A.U. Chamot, A. (1989). Learning strategies in SLA. Cambridge University Press.

[3] Rost, M, et al (1991). Learner use of strategy in interaction. A journal of applied linguistics, VOL. 41.235-237

[4] Rost, M. (1990). Listening in language learning, New York: Longman.

[5] Willing, K. (1985). Helping adults Develop their learning strategies, Sydney. Adult Migrant Education service.

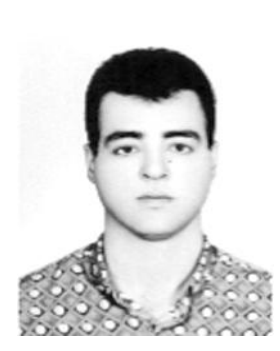

Ramin Taherkhani was born in Tehran, IRAN on January 5, 1971. He was awarded BA in English translation and interpretation in 1996 (Islamic Azad university-Takestan branch). In summer 2002, he got his MA in TEFL from Islamic Azad University - Garmsar branch, IRAN.

$\mathrm{He}$ is now a university teacher in Islamic Azad University -Takestan branch. He has taught General English for eight years. Nowadays he is working on a paper concerning listening and time. He cooperates with (FIVB) as a translator too. 